\title{
Economics of invasive species policy and management
}

\author{
Rebecca S. Epanchin-Niell
}

Received: 3 October 2016/Accepted: 7 March 2017/Published online: 16 March 2017

(C) The Author(s) 2017. This article is an open access publication

\begin{abstract}
This article examines the use of economic analysis to inform bioinvasion management, with particular focus on forest resources. Economics is key for understanding invasion processes, impacts, and decision-making. Biological invasions are driven by and affect economic activities at multiple scales and stages of an invasion. Bioeconomic modeling seeks to inform how resources can be optimally allocated across invasion management activities-including prevention, surveillance programs for early detection and management, and controlling invasion populations and spread-to minimize the long-term costs and damages. Economic analysis facilitates understanding of decisions by public and private decision-makers, gaps between these, and the design of policies to achieve socially desirable outcomes. Private decisionmakers may undercontrol invasions relative to socially optimal levels, because they generally account for their own costs and benefits of control but less often for broader ecosystem impacts or future spread across the landscape. Economic analysis considers approaches for increasing private invasion
\end{abstract}

Guest Editors: Andrew Liebhold, Eckehard Brockerhoff and Martin Nuñez / Special issue on Biological Invasions in Forests prepared by a task force of the International Union of Forest Research Organizations (IUFRO).

R. S. Epanchin-Niell ( $₫)$

Resources for the Future, 1616 P St. NW, Washington,

DC 20036, USA

e-mail: Epanchin-niell@rff.org management and evaluates feedbacks between ecological and economic systems that can affect policy outcomes. Future research should continue evaluation and design of control strategies across the biosecurity continuum and across species to enhance cost-effectiveness, better incorporate uncertainty into policy design, increase focus on incentives and behavioral tools to influence private behaviors that affect invasion spread, and incorporate invasive species consideration within broader systems-focused science. In addition, challenges in valuing biodiversity and ecosystem service impacts and the costs and effectiveness of control measures are key data gaps. Greater collaboration between decision-makers and researchers will facilitate development and communication of usable economic research.

Keywords Policy design - Forest biosecurity · Bioeconomics · Cost-efficiency · Prevention and control

\section{Introduction}

This article examines the use of economic analysis to help inform biological invasion management, with particular focus on reducing impacts to forests and forest resources. Although economics of invasive species is often equated with assigning monetary values to damages caused by biological invasions, economics is a diverse discipline that is variously 
defined as the study of scarcity, the study of how people use resources, and the study of decisionmaking. Environmental and resource economics, more specifically, applies economic theory and methods to environmental issues to improve management strategies. Therefore, the goals of economic analysis of invasive species management are often to better understand trade-offs associated with actions or policies-a challenge for which damage values are just one input.

Indeed, economics is central to understanding and managing biological invasions, as economic activities such as trade, travel, and the movement of goods and people are key drivers of the introduction and spread of invasive species, and their establishment and spread can reduce benefits from invaded systems. Economics also can be used to describe how individuals and public institutions respond to or make choices about biological invasions and why public and private choices often differ. Furthermore, economics provides tools that can help design and evaluate invasive species policies and regulation to better achieve social objectives, including resource allocation to maximize the return on invested resources (i.e., get the biggest bang for the buck).

While only a fraction of introduced non-native species cause significant ecological or economic harm, our focus is on the harmful species, which I refer to as invasive. Natural and plantation forest invasions can negatively affect timber production, biodiversity, recreation values, and aesthetic values, as well as key biophysical and biochemical processes such as hydrological dynamics, fire frequencies, and carbon sequestration (Moser et al. 2009; Simberloff 2011). Notorious forest invaders include pathogens such as chestnut blight (Cryphonectria parasitica) and sudden oak death (Phytophthora ramorum), invertebrates such as emerald ash borer (Agrilus planipennis) and the night crawler (Lumbricus terrestris), plants such as tree-of-heaven (Ailanthus altissima) and garlic mustard (Alliaria petiolata), and mammals such as wild pigs (Sus scrofa).

Because forest invasions impose costs, in terms of market and nonmarket impacts and reduced ecosystem service provisioning, public and private decisionmakers often choose to invest in management to reduce these impacts. Management itself can incur direct, indirect, and opportunity costs, where opportunity costs are the values that are forgone by implementing a particular management strategy (e.g. lost trade values from implementing a quarantine, or forgone profits from delaying timber harvest). Estimates of both damage and management costs are key for decision-making and justifying resource investments. While direct expenditures on invasive species management are often straightforward to quantify and readily considered, opportunity costs are more often overlooked. Similarly, market impacts, such as timber harvest value losses, are better understood and accounted for than damages affecting values not measured in typical economic markets, such as aesthetic or recreation values. However, nonmarket values and ecosystem service impacts are receiving increasing attention and often are of even greater value (see reviews in Holmes et al. 2009, 2014; Born et al. 2005; Rosenberger et al. 2012).

Estimation of the monetary value of invasion impacts or mitigation costs is challenging because of complex invasion dynamics and economic processes, as well as the difficulty of monetizing biodiversity and ecosystem service benefits, among others. Estimating invader damage impacts requires accounting for bioeconomic features of the invasion, including spread, control, and damage processes (Kovacs et al. 2010, 2011a, b; Haight et al. 2011). Behavioral responses by individuals, stakeholders, and producers on the landscape also can affect the damages posed by an invader and the welfare consequences of different policies or control strategies (Settle et al. 2002; Finnoff et al. 2005, 2010a). For example, the impacts of a forest invasion may depend on whether timber production is adapted to reduce damages, recreationalists shift activities to alternate sites, or homeowners protect their trees through pesticide application.

The primary focus of this article is decisionmaking regarding policy design and resource allocation for minimizing forest invasion impacts. It provides an extensive review of the existing literature to highlight the types of economic analyses that have been applied to biological invasions, what has been learned, and future directions for research and management (for other reviews on the economics of managing bioinvasions, see Olson 2006; Gren 2008; Finnoff et al. 2010a). The next section discusses the relevance of external costs and public goods concepts to invasive species and the principles of costeffective and cost-efficient management. The following sections describe economic analysis of forest 
invasion management, organized following the stages of an invasion and associated safeguarding options. The article concludes with a discussion of future research needs and management and policy challenges.

\section{Overview of economic concepts applied to invasive species management}

Invasive species management can be considered from the perspectives of a private decision-maker (forest owner, timber operation manager, goods importer, forest recreationist) or a public decision-maker (policy-maker, public lands manager). Public decision-makers generally are assumed to account for the full range of costs associated with a forest invasion, such as from the loss of biodiversity and timber and recreation values, the alteration of hydrological or fire dynamics, and the potential spread to other lands. Private decision-makers, on the other hand, have incentives to manage invasions based on their own goals and likely will not take into account all the social costs of an invasion. For example, a private land manager may focus only on damages accruing to his own property and may not account for costs such as from loss of carbon sequestration due to invader impacts. Thus, private managers may not invest as much in invasive species control as is socially desirable. Indeed, many benefits of invasion management are enjoyed by a range of stakeholders and are nonexcludable (i.e., their enjoyment by one stakeholder does not reduce benefits to other stakeholders). Invasion management thus has public good characteristics, further implying a role for public policy and regulation to align the incentives of private decision-makers with the achievement of social goals for invasion management (Perrings et al. 2002).

Most analysis of invasive species management focuses on optimal public decision-making_identifying the socially optimal levels of invasion management. However, economic models also have been developed to represent the incentives and constraints facing private decision-makers in order to evaluate how their management would change in response to regulations or incentives schemes, with the goal of designing policies that better align private management with socially preferred outcomes (Eiswerth et al.
2016; Marbuah et al. 2014; Holmes et al. 2014; Epanchin-Niell and Hastings 2010).

The divergence between private management and public goals arises ubiquitously across invasion stages. For example, beneficiaries of imported goods often are not the same entities that incur costs from invasions resulting from those imports (Lovett et al. 2016). A forest owners association evaluating implementation of an early detection surveillance system for new invaders may not take into account the benefits of that system to city dwellers whose urban trees also would benefit from the system (Epanchin-Niell et al. 2014). Landowners whose forestlands are being decimated by an invasive pest likely will not fully account for the benefits of their management for other forest owners when determining how much to invest in invasion mitigation, and therefore they may control less than is socially desirable (Aadland et al. 2015). Similarly, a forest owner may overlook the impacts of preemptive harvesting in response to an anticipated pest invasion on the structure and function of the forest ecosystem (Kizlinski et al. 2002). For these reasons, public management often is needed to ensure appropriate levels of invasion management to achieve social objectives.

To effectively address biological invasion risks, a public decision-maker must evaluate complex tradeoffs to determine what actions will achieve the best outcomes for society. These outcomes can be achieved through top-down implementation (e.g., regulation or public implementation) or design of policies or incentives to alter private behavior. Examples of topdown strategies include state-implemented surveillance programs and mandated control of noxious weeds on private lands. Alternatively, a cost-share program may be implemented to enhance private control of an invader. When designing policy interventions, analysis should consider both the intended and unintended consequences of a policy as entities react to the policy or the invader (Finnoff et al. 2005).

Underlying public decision-making is the challenge of how to efficiently allocate scarce monetary, natural, human, or other resources. Economic analysis commonly seeks to determine how limited resources should best be spent. In addition, it often is worth asking how much should be spent-what should the budget be or what would be the gains from increasing available resources? There are a number of approaches for determining cost-effective resource allocation, 
including benefit-cost analysis, return on investment analysis, and more complex optimization approaches (Table 1). The applicability of these approaches depends on the decision context, management context, and objectives. In general, benefit-cost analysis identifies if a project's benefits are greater than its costs (i.e., is it cost-effective?); return on investment analysis ranks a set of predefined projects based on their relative cost-effectiveness (i.e., which projects are more cost-effective?); and optimization approaches aim to design the investment or management strategy that will provide the biggest possible bang for the buck, achieve management objectives in the most economical way, or provide the greatest overall benefits.

Benefit-cost analysis is appropriate for evaluating whether to engage in a specific, defined invasion mitigation or biosecurity project. This approach assesses whether the benefits of a project outweigh its costs to determine if it is a worthwhile investment (e.g., Keller et al. 2007; Zavaleta 2000). The assessment requires estimates of benefits and costs, measured in the same units (generally monetary). Although estimating the monetary value of invasion impacts or mitigation is challenging because of complex invasion dynamics and difficulty measuring, predicting, and monetizing impacts, in some cases it may be possible to monetize values for a subset of affected benefits and show a project's cost-effectiveness based on those values. However, to show that a project is not worthwhile, a full accounting of benefits would likely be needed, as excluding values incorrectly assumes they have zero value.

Whereas benefit-cost analysis can be used to evaluate projects individually, return on investment analysis can be used to prioritize among a set of discrete, independent investment options, such as potential eradication or control projects across a national forest. Options are prioritized based on their expected return on investment (Boyd et al. 2015). The projects that provide the highest benefits relative to costs (i.e., ratio of benefits to costs) are those that will provide the biggest bang for the buck. Cost-effective resource allocation involves selecting projects in order of decreasing benefit-to-cost ratios until the budget is exhausted. This type of analysis is desirable because of its transparency and apparent simplicity. In addition, benefits do not need to be measured in monetary units, as long as they are measured comparably across projects. However, return on investment analysis has not often been widely applied to invasive species management (Boyd et al. 2015, but see, e.g., Murdoch et al. 2007; Donlan et al. 2015). There are several likely reasons for this. First, managers often are not

Table 1 Potential solution approaches for identifying cost-effective or efficient resource investments for invasion management

\begin{tabular}{|c|c|c|c|}
\hline Approach & Use & Method & Examples \\
\hline $\begin{array}{l}\text { Benefit-cost } \\
\text { analysis }\end{array}$ & $\begin{array}{l}\text { Determine whether a project is a cost- } \\
\text { effective investment }\end{array}$ & $\begin{array}{l}\text { Determine whether benefits are } \\
\text { greater than the costs }\end{array}$ & $\begin{array}{l}\text { Keller et al. (2007) and Zavaleta } \\
\text { (2000) }\end{array}$ \\
\hline $\begin{array}{l}\text { Return on } \\
\text { investment } \\
\text { analysis }\end{array}$ & $\begin{array}{l}\text { Prioritize allocation of budget across a } \\
\text { set of discrete, independent projects } \\
\text { (e.g. rank projects based on cost- } \\
\text { effectiveness) }\end{array}$ & $\begin{array}{l}\text { Select projects in decreasing order } \\
\text { of benefits divided by costs } \\
\text { (benefit-to-cost ratio) }\end{array}$ & $\begin{array}{l}\text { Murdoch et al. (2007) and Donlan } \\
\text { et al. (2015) }\end{array}$ \\
\hline Optimization & $\begin{array}{l}\text { Determine the efficient level of } \\
\text { investment (i.e. maximize net } \\
\text { benefits); design management to } \\
\text { best achieve management objective }\end{array}$ & $\begin{array}{l}\text { Apply dynamic optimization, } \\
\text { optimal control, etc. within a } \\
\text { bioeconomic modeling } \\
\text { framework }\end{array}$ & $\begin{array}{l}\text { Olson and Roy (2002), Eiswerth and } \\
\text { Johnson (2002), Epanchin-Niell } \\
\text { et al. (2012), (2014), Haight and } \\
\text { Polasky (2010), Burnett et al. } \\
\text { (2007), Baker and Bode (2016), } \\
\text { Sharov and Liebhold (1998) and } \\
\text { Sims (2011); majority of studies } \\
\text { cited in this review }\end{array}$ \\
\hline $\begin{array}{l}\text { Optimal } \\
\text { policy } \\
\text { design }\end{array}$ & $\begin{array}{l}\text { Determine optimal policy parameters } \\
\text { (e.g. tax level, inspection rate) to } \\
\text { alter private behavior or decision- } \\
\text { making to achieve management } \\
\text { objectives }\end{array}$ & $\begin{array}{l}\text { Apply dynamic optimization, } \\
\text { optimal control, etc. using a } \\
\text { bioeconomic model that accounts } \\
\text { for private decision-making }\end{array}$ & $\begin{array}{l}\text { Springborn et al. (2016), Mérel and } \\
\text { Carter (2008), McDermott (2015), } \\
\text { Fenichel et al. (2014) and Liu and } \\
\text { Sims (2016) }\end{array}$ \\
\hline
\end{tabular}


choosing among discrete independent projects, but instead choosing how much funds to allocate to each project. Also, benefits across projects often are not independent. For example, control of an invader at one location can influence the effectiveness of controls at another location. Finally, because invasions spread over time and space, the benefits of any given project can be challenging to predict and require substantial ecological and economic modeling to obtain even coarse estimates.

Management of invasive species often requires making decisions about how much to control or what level of a measure to implement, rather than a simple binary decision of whether to fund or not fund. In general, decisions take the form of choosing how much to invest in a particular action or how stringent a policy should be to provide the greatest net gains. Management questions that aim to identify the level (or timing) of investments that will best achieve the management objective require optimization approaches. Specific objectives can include choosing the level of treatment to minimize the sum of costs of treatment and damages from the invader (Olson and Roy 2002; Eiswerth and Johnson 2002; Finnoff et al. 2010b; Epanchin-Niell and Wilen 2012) or to maximize the flow of future benefits from control efforts minus the costs of management (Polasky 2010). Similarly, a private timber producer might choose how much to control an invasion or when to harvest timber threatened by invasion in order to maximize long-term profits (Aadland et al. 2015). These approaches aim to identify efficient solutions, which maximize net benefits, from the decision-maker's standpoint.

Designing optimal strategies or investment levels to achieve desired management outcomes often requires approaches that integrate ecological and economic models (bioeconomic models), because the costs and benefits of management depend on how management affects the dynamics of the focal system. Bioeconomic modeling is the development and application of integrated models of relevant ecological and economic systems that can be simulated or incorporated into optimal control frameworks to optimize or evaluate potential management strategies. These models can account for both social and ecological responses to policies, such as how a tax or inspection regime will alter behavior or decisions, and hence invasion outcomes (e.g. Springborn et al. 2016; Fenichel et al. 2014). Embedding models of private decision-making within bioeconomic models enables the outcomes of different policies to be evaluated to inform their design.

Bioeconomic modeling requires identifying the critical features and dynamics of the relevant ecological and economic systems, determining how to represent complex dynamics in tractable mathematical forms, and developing and applying appropriate methods to identify the set of (potentially temporally and spatially varying) interventions that best achieves a desired set of objectives. Such models also require substantial empirical analysis to develop inputs and to parameterize and calibrate them to realistically represent focal systems. Indeed, developing bioeconomic models that are both ecologically sound and capable of addressing practical management issues poses challenges.

In general, solutions to bioeconomic optimization models that aim to maximize net benefits identify the levels of investment or actions that equalize marginal costs and marginal benefits, such that the benefits from the last unit of investment just equal the cost of that investment. This approach defines a cost-efficient solution from the decision-maker's perspective (Epanchin-Niell and Hastings 2010). Budget and other constraints can force managers to deviate from this basic economic rule, and analysis can identify how augmenting management resources could increase net benefits (e.g., Burnett et al. 2007; Epanchin-Niell et al. 2012).

\section{Application of bioeconomic models to improve management of biological invasions}

Interventions to mitigate the impacts of invasive species include reducing the rate of invasive species introduction (prevention), eradicating new invader populations, and reducing damages by slowing the spread of invasions across the landscape or adapting to an invader's presence through control or altered management practices. ${ }^{1}$ In addition, monitoring is key to most invasion mitigation strategies-for

\footnotetext{
1 The specific choice of measures to control an invader will vary across species and contexts, but typically aim to reduce invader populations or slow population growth or dispersal. Such controls can directly impact invader populations, such as through pesticide application, trapping, or mechanical control, or indirectly such by habitat alteration (e.g. forest thinning).
} 
knowing what and where to control and for evaluating the effectiveness of management actions.

Economic analyses often aim to optimize prevention, control, or monitoring investments to minimize the total costs and damages resulting from invasion impacts and management. Such analyses must account for the multifaceted trade-offs among economic activities, species impacts, and control interventions, as well as the underlying dynamics of biological invaders that make their management and analysis particularly complex.

Bioeconomic models can provide intuition about trade-offs or inform design of specific management activities. Most bioeconomic invasion work to date has focused on optimizing management within a single intervention context, holding investments at other stages of the invasion fixed or as governed by specific investment rules. This is unsurprising given the complexity of evaluating policies even within a single intervention stage. Accounting for interdependencies across invasion stages is computationally more challenging but also of key importance, and examining control at any invasion stage requires some evaluation or assumptions of outcomes at subsequent stages.

The following description of economic contributions to the management of invasive species is organized by five interconnected policy design challenges: (1) enhancement of invasive species prevention efforts, (2) design of cost-efficient surveillance and invasion monitoring, (3) optimal management of established invasions, (4) private control of invasion spread, and (5) accounting for uncertainty.

Invasion prevention

Invasive species are moved around by people and trade, and preventing the introduction of species into new locations is one means for avoiding their potential damages (Perrings et al. 2002). Invasive species can be introduced intentionally, such as via nurseries or for plantation forestry, or unintentionally as hitchhikers on imports or in baggage. ${ }^{2}$ Economic analyses of

\footnotetext{
$\overline{2}$ Invasive plants have most often arrived as intentional horticultural or ornamental introductions, but also as crop seed contaminants (Reichard and White 2001; Pyšek et al. 2009). Pests and pathogens arrive most often as hitchhikers in passenger baggage or imported goods. Live plant imports
}

prevention measures largely focus on reducing propagule pressure of potential invaders. For example, introductions (intentional and unintentional) can be prevented or reduced via bans or tariffs on risky imported goods. In addition, unintentional introductions can be reduced through pre-entry mitigation measures and by interceptions of infested materials through border inspections.

Economic studies have examined optimal prevention investments based on weighing prevention investments against expected postinvasion costs as well as the trade-offs between prevention and control investments (Burnett et al. 2008; Olson and Roy 2005; Kim et al. 2006; Leung et al. 2005; Horan et al. 2002; Moffitt and Osteen 2006). The optimal strategy for prevention necessarily depends on the long-term costs to society of an invasion if it were to occur (Olson 2006; Leung et al. 2002). Long-term damages from establishment depend on the likelihood of establishment, localized damage impacts, species' temporal characteristics such as lags and rates of spread, and effectiveness and costs of controls postestablishment, among other factors (Epanchin-Niell and Liebhold 2015; Leung et al. 2002). Studies on prevention have variously accounted for how invader damage and growth characteristics, introduction probabilities, and the costs and effectiveness of postestablishment control options affect optimal investments in prevention. As the costs of postinvasion control increase or effectiveness decrease (or the costs of prevention decrease and prevention effectiveness increase), optimal investment in prevention increases, because invasion establishment becomes relatively more costly.

For example, Carrasco et al. (2010b) develop a comprehensive bioeconomic model that considers the exclusion, detection, and control of multiple invasive species and find that less exclusion and more control resources should be allocated to invasive species characterized by Allee effects, low rate of satellite colonies generation, and low propagule pressure.

\footnotetext{
Footnote 2 continued (e.g., house and garden plants and ornamentals) are a particularly strong pathway for introduction of terrestrial invertebrates and forest pests and pathogens (Liebhold et al. 2012; Roques et al. 2009), with solid wood packaging material also a key pathway for wood-boring and bark beetles (Liebhold et al. 2012). Forest pests also can be transported on conveyances, containers, and ships (Hulme 2009).
} 
Horan et al. (2002) examine how prevention investments should be allocated across multiple potential invasion pathways and find that prevention should be applied across pathways such that the marginal cost of prevention in each pathway equals the marginal benefits from prevention in that pathway, accounting for introduction probabilities across all pathways.

Importantly, although perfect prevention is neither feasible nor cost-effective, investing in prevention efforts nonetheless provides benefits by reducing the likelihood of invasion and delaying impacts, thereby reducing expected damages. However, even in cases where investing more in prevention may appear optimal, if decision-makers are risk averse they may nonetheless underinvest in prevention, preferring to focus on postinvasion control. This could happen because prevention appears more risky as it targets an uncertain invasion possibility, whereas control addresses a known problem (Finnoff et al. 2007).

A key measure for informing exclusion, quarantine, and control policies is pest risk analyses, which evaluate the probability of a species arriving and establishing as well as the probability and magnitude of damages if establishment were to occur (Andersen et al. 2004; Stohlgren and Schnase 2006; Hulme 2012; Leung et al. 2012; Simberloff et al. 2005). Studies have found positive net benefits from using pest risk assessments to inform exclusion decisions across a range of contexts, including plant, bird, and reptile imports (Keller et al. 2007; Springborn et al. 2011, 2015; Schmidt et al. 2012). Additionally, economists have developed an economically and statistically rigorous approach for screening nonindigenous species imports in a way that efficiently trades off the benefits of excluding potential invaders with the costs to consumers of unnecessarily rejecting species that will not become invasive (Springborn et al. 2011, 2015; Lieli and Springborn 2012; Schmidt et al. 2012). These studies find substantial economic gain from implementing such a screening strategy.

While exclusion represents a binary decision as to whether to allow importation of a particular good, various market and financial tools also have been considered for reducing invasion establishment. These include price-based instruments (e.g., Pigouvian taxes, tariffs, ambient taxes), tradeable risk permits, liability insurance, and environmental performance bonds, among others (Barbier and Shogren 2004; Knowler and Barbier 2005; Jones and Corona 2008; Horan and
Lupi 2005; Fernandez 2011; Thomas and Randall 2000).

These financial mechanisms generally can serve two purposes: incentivizing risk reduction by producers of the risk (through abatement activities) and cost recuperation (to help pay for invasion impacts). For example, Pigouvian taxes aim to tax entities so that they produce invasion risk (expected damages from invader introduction) at exactly the level where the marginal cost to society of an additional unit of invasion risk just equals the marginal cost to producers of reducing risk by one more unit; this represents a socially efficient level of invasion risk. In the absence of a tax, producers would abate invasions only to the point where the cost of an additional unit of abatement just equaled their own cost they incurred from that extra unit of invasion risk, rather than accounting for the costs accrued to all of society from that risk.

Although economically efficient in theory, taxes and other economic tools are difficult to apply in practice for a variety of reasons. In particular, application of typical environmental economic tools is hindered by difficulty in predicting species' invasiveness, time tags between introduction and invasion damages, invader populations growing rather than dissipating over time, the difficulty of quantitatively attributing risk to specific entities or identifying who was responsible for a particular invasion, and the challenge of valuing invasion damages monetarily. Perhaps for these reasons, few market incentives have received practical application. Also, most have been considered in the context of preventing aquatic or agricultural invaders, rather than forest invasions in particular.

Tariffs, or taxes on imported commodities, aim to reduce risk by reducing the volume of risky imports. The general principle in tariff design is that the tariff should reflect the magnitude of expected damages associated with the imports (McAusland and Costello 2004); however, adjustments in production, consumption, imports, and land use in the importing country that result from the tariff can, in some cases, counteract the tariff's benefits by increasing susceptibility to invasions that do occur (Costello and McAusland 2003; Tu et al. 2008). Thus, evaluating the effectiveness and efficiency of tariffs for reducing invasive species introductions requires consideration of price and production effects across sectors (Gren 2008). Tariffs also can be applied in conjunction with other 
tools. For example, McAusland and Costello (2004) consider multiple trade-related policies and find that the optimal policy generally involves a combination of inspections and tariffs. Similarly, Mérel and Carter (2008) report that tariffs combined with fines on commodities found to be infested outperform tariffs alone, because the additional fines incentivize abatement by exporters. Nonetheless, tariffs addressing invasion risk may be challenged politically by the difficulties in differentiating tariffs aimed at protectionism (i.e., meant to protect domestic producers from cheap imports) from those actually aimed at addressing invasion risk (Margolis et al. 2005).

Preventing forest invasions also can be achieved by reducing pest loads on imported goods through preborder interventions. For example, International Standards for Phytosanitary Measure No. 15 (ISPM 15) mandates treatment of wood pallets to reduce introduction of wood borers and bark beetles. Leung et al. (2014) evaluated the net benefits from implementation of ISPM 15 by modeling the anticipated reduction in pest introductions and associated damages from this policy and comparing that with the trade costs imposed by the policy. Their model accounts for changes in trade volume over time, the response of trade flows to the increased trade costs, the effectiveness of the policy at reducing pests in packaging material, and depletions in potential pest pools over time. They found that the policy could generate greater than US $\$ 11$ billion in cumulative net benefits by 2050 , despite the policy's substantial costs, by reducing the rate of invasions relative to the absence of the policy.

A substantial literature also has focused on determining optimal levels of border inspections to prevent invasive species introductions. Inspections are a key measure for reducing invasive pest introduction by (1) providing information about risks across commodities to inform other policy interventions, (2) incentivizing producers to abate invasion risk in exported goods (to avoid penalties associated with interceptions), and (3) intercepting infested shipments at the border. A majority of studies have focused on inspection design to maximize interceptions and minimize acceptance of infested shipments or units (e.g., Surkov et al. 2009; Yamamura et al. 2016; Chen et al. under review). These studies highlight that optimal inspection policies focus more resources on the higher-risk commodities. For example, Chen et al. (under review) find that inspections should target the largest and "dirtiest" shipments most intensively to minimize total propagule pressure from accepted shipments. They provide statistical approaches for estimating underlying infestation rates from historic interception data. Moffitt et al. (2008) consider optimal border protection under extreme uncertainty. Analyses also have specifically accounted for the value of inspections for learning about risks across pathways to improve targeting over time to minimize accepted infested shipments over the long term (e.g., Springborn 2014).

Importantly, some studies also have highlighted the important role of inspections for encouraging exporters to reduce infestation rates in their commodities through abatement (Ameden et al. 2007, 2009; Springborn et al. 2016). Springborn et al. (2016) evaluate an anticipated inspection policy shift by the US Department of Agriculture's Animal and Plant Health Inspection Service (USDA APHIS) regarding inspection of live plant imports-a primary pathway for forest pest introductions. Under this policy, exporters will be categorized into groups based on risk, with higher-risk groups subjected to more intensive inspections. Using a calibrated model of exporter behavior and inspection, Springborn et al. (2016) find that a shift to this form of risk-based inspection could cut the rate of infested shipments accepted into the United States by one-fifth, simply by reallocating existing surveillance resources. The gains are achieved both by targeting riskier commodities more intensively and by incentivizing exporters to increase abatement in hopes of moving to or remaining in the lower-risk group, which is inspected less intensively. Fernandez and Sheriff (2013) consider the additional role of technical assistance in reducing introductions via trade by enhancing abatement efforts by exporters. They find that providing technical assistance for abatement can be part of an optimal policy that also includes inspections and penalties for interception of infested shipments.

An aspect of prevention policies that has not been widely examined in economics literature on bioinvasions is the extent to which more stringent regulation of imports could increase illegal imports, which are likely to be riskier than goods entering through regulated pathways. Invasive species introduction via passenger baggage and mail-order shipments also has received little attention from economists, despite the importance of these pathways. 
Early detection and monitoring surveillance

Although prevention measures can reduce the rate of new forest invasions, $100 \%$ prevention is neither feasible nor cost-efficient. Thus, damaging invaders regularly establish in new regions of the world, and control efforts may be implemented to reduce their impacts. In order to control an invasion, however, the incursion generally must first be detected. Indeed, a key safeguarding approach to mitigate damages is early detection and rapid response (Liebhold et al. 2016; Lodge et al. 2006). Greater surveillance intensity (e.g., larger numbers of traps deployed or visual surveys conducted to detect new populations) generally increases the probability of detecting invasions earlier, when their control is less costly and more likely to be successful. However, more intensive surveillance is also more costly. Hence, designing surveillance programs for early detection of forest invaders requires balancing the cost of surveillance with the benefits from earlier detection of potential incursions. In addition, programs must decide how to allocate surveys across the landscape, accounting for how risks and costs vary across locations.

Economic analysis generally has been absent from design and evaluation of early detection monitoring systems, in practice. Instead, resources often have been allocated based on ad hoc processes (such as dividing resources equally among states), political considerations, or relative risk maps. An increasing literature has been aimed at optimizing the design of invasive species surveillance programs (trapping programs and field surveys) to enhance cost-effectiveness in different contexts, including one-time survey programs and long-term surveillance efforts (e.g., Kaiser and Burnett 2010; Mehta et al. 2007; Bogich et al. 2008; Homans and Horie 2011; Epanchin-Niell et al. 2012, 2014; Horie et al. 2013; Cacho and Hester 2011; Moore and McCarthy 2016; Yemshanov et al. 2015; Holden et al. 2016; Chadès et al. 2011). Each subsequent study has typically relaxed assumptions of previous studies to increase the realism and applicability of the modeling approach for designing surveillance in specific systems. Some have focused on early detection of forest invaders, including brown treesnake (Boiga irregularis) (Kaiser and Burnett 2010), gypsy moth (Lymantria dispar) (Homans and Horie 2011; Bogich et al. 2008; Epanchin-Niell et al. 2012; Berec et al. 2015; Holden et al. 2016), wood borer and bark beetles (Epanchin-Niell et al. 2014), emerald ash borer (Yemshanov et al. 2015), and oak wilt (Horie et al. 2013).

Studies typically have sought to either minimize total long-term costs, including survey, damage, and control costs, or maximize detections subject to a budget constraint on total survey effort. They generally have found that implementing well-designed survey programs can substantially reduce costs. For example, Epanchin-Niell et al. (2014) found that implementing an optimized trapping program for wood borers and bark beetles in New Zealand could reduce long-term costs by $40 \%$ relative to the absence of such a program. The existing body of research provides useful frameworks for designing cost-effective surveillance systems for detecting new invasions, as well as qualitative guidance identifying when surveillance is most worthwhile. Specifically, greater investments in surveillance generally are warranted when establishment rates are high, expected invasion damages are high, and surveillance is less costly. For example, surveys targeting new incursions of wood borers and bark beetles are likely to provide the biggest bang for the buck when they focus more effort in areas that receive high amounts of imports associated with wood packaging material and are located near high-value, at-risk resources (Epanchin-Niell et al. 2014). Also, when designing long-term surveys, greater survey effort may be warranted at the start of a program than later in the program if invader establishment rates are relatively low (Holden et al. 2016). Intensive early surveys allow quick detection of any populations that already have established before the start of the program, and lower subsequent effort may be optimal to detect new populations that establish later on.

Epanchin-Niell et al. (2014) and Homans and Horie (2011) endogenize the decision whether to attempt eradication following detection, accounting for managers' postdetection control choices in the design of the surveillance program. Others have framed the detection challenge within a broader decision framework that includes prevention decisions as well, recognizing their interdependency (Rout et al. 2011, 2014; Moore et al. 2010; Polasky 2010). An outcome of this work (Rout et al. 2014) is that if a species can be controlled when its presence is uncertain, a mixed strategy of surveillance and control may sometimes be optimal. 
Whereas most economic analyses have focused on how much to survey or where to allocate surveys across heterogeneous landscapes, Berec et al. (2015) consider the local spatial arrangement of survey locations, including rectangular, alternating, and fuzzy grids, and find that the specific arrangement does not matter much unless the survey instruments are highly sensitive.

In addition to surveillance focused on early detection, surveys are critical for informing eradication and management efforts. In deciding when to declare eradication, the costs of increased confidence regarding eradication success (through continued surveys) must be balanced with the costs of potentially declaring eradication too early (and incurring large costs from the invasion resurging) (Regan et al. 2006; Rout et al. 2009). D'Evelyn et al. (2008) highlight the value of information gained through control efforts, focusing on management of the brown tree snake, a forest invader. They show that harvesting an invasive species can provide the dual benefits of population reduction and learning about the invasive species' population size. Studies also have aimed to optimize surveillance efforts that are part of ongoing management programs for established invaders, with a focus on detecting and controlling outlying infestations that can contribute to rapid spread (e.g., Cacho and Hester 2011; Hauser and McCarthy 2009; Moore and McCarthy 2016; Homans and Horie 2011).

Even when eradication and control are infeasible, continued surveillance nonetheless can be beneficial sometimes by providing early warning to communities along the expanding invasion front. This can allow them to prepare for the invader's arrival, such as through preemptive efforts to protect ash trees from emerald ash borers in affected communities. However, if minimal options are available for abating damages or slowing the spread of invasives through advanced detection, the value of surveillance will be low, and the costs of an active surveillance program may not be justified.

Most of the existing literature has focused on active surveillance (e.g., planned visual or trapping surveys), but passive surveillance in the form of public reporting also serves as a key source for new detections (Hester and Cacho 2017). This has been incorporated into some optimal surveillance work by simply assuming that a population of an established pest will be detected after some time period on the landscape if not detected by a trap (Epanchin-Niell et al. 2014). However, Cacho and Hester (2011) and Cacho et al. (2010) have explicitly evaluated the importance of passive surveillance in weed detection and eradication efforts and have shown how this can greatly reduce program costs.

Some economic studies of surveillance and monitoring for forest invasions also have accounted for uncertainty in knowledge about the state of invasion (e.g., about the probability that eradication has been successful or that a pest or disease is present) by enabling expectations about the probabilities of a particular state to be updated over time based on survey observations (Regan et al. 2011; Haight and Polasky 2010; Rout et al. 2009, 2014; Chadès et al. 2011). These models determine optimal interventions based on current beliefs about the state of the system and how actions should change as beliefs are updated.

\section{Optimal control of established invasions}

Following detection and delimitation of a new invader, managers are faced with evaluating control options, their costs and effectiveness, and whether and how much to control the species. What method should they use? Should they seek to immediately eradicate the population or aim to contain the invasion, slow its spread, or mitigate damages? Or should they do nothing?

Important to these decisions is understanding what controls are effective to reduce a forest invader's population or to mitigate damages. What would be the costs relative to the benefits of different control mechanisms, given their relative effectiveness? For example Wu (2000) determines optimal herbicide applications over time, given seed bank dynamics of a weed. Blackwood et al. (2012) use a bioeconomic model to examine the synergistic effects of applying multiple control tactics to eradicate the gypsy moth, accounting for the species' population dynamics and the costs of different control measures. They find that combining pesticide application and mating disruption techniques simultaneously can be more cost-effective than either technique alone. In the context of salvage harvesting in a forest affected by a pest outbreak, Sims (2011) finds that harvest should occur sooner when timber values are large and nontimber values are markedly reduced by dead or dying trees. In forests subject to interacting disturbances such as fire and 
invasive species and susceptible to crossing irreversible ecological thresholds, approaches from rangeland bioeconomics may offer insights into optimal harvest and restoration investments (Eiswerth et al. 2016).

A key feature of invasions is that they spread, generally causing increasing damages over time as the extent of the invasion grows. Hence, a substantial amount of research has focused on optimal strategies that account for how control affects invasion spread, and thus damages, over time and space (see review in Epanchin-Niell and Hastings 2010). Much of this work has focused on how much to control an invasion given its growth over time and whether eradication, containment, slowing the spread, or abandonment is the optimal strategy. General findings from existing work (e.g., Olson and Roy 2005, 2008; Eiswerth and Johnson 2002; Sharov and Liebhold 1998; EpanchinNiell and Wilen 2012; Finnoff et al. 2010b) are that more control generally is warranted for invasions that are expected to spread fast, invade large areas, cause high damages, and have low control costs. Eradication is most likely to be optimal if the invasion is small when detected and if reintroduction is less probable or less frequent. Therefore, eradication may be optimal early in an invasion, but optimal policies shift to slowing the spread and eventually abandonment as the size of the invasion increases. Slowing the spread of an invasion can provide substantial benefits by enabling the continued provisioning of ecosystem benefits or delaying damages for a longer time, and it may allow time for new control technologies to be developed or for affected stakeholders to adapt.

When new invaders are first detected, managers often take a "wait and see" approach, perhaps to learn how damaging the species will be prior to beginning a costly control program. Economists have analyzed this choice using a real options approach, accounting for uncertainties about the invader's impact, as well as the costs associated with responding to an invader that turns out to not be very damaging (Marten and Moore 2011; Saphores and Shogren 2005; Sims and Finnoff 2013). Saphores and Shogren (2005) evaluate the optimal timing of a fixed control investment and how much should be spent on research to learn about the species' ecological and economic characteristics. Others use the real options approach to examine whether a "wait and see" approach is justified when faced with uncertainty in spread rates and the damages that could be avoided through a control policy (Sims and Finnoff 2013; Sims et al. 2016). These studies show that the source of uncertainty and degree of policy irreversibility matter. If policy-makers can cancel the control policy in the future and recoup a portion of the costs, a "wait and see" approach is difficult to justify unless the invasive species has a low spread rate with low uncertainty. For fast-spreading species, the large potential returns from immediate control incentivize larger and immediate investments, even though the volatility of spread makes investments more risky. These findings support rapid invasion control response, even when faced with invader uncertainty, particularly when the invasion is spreading quickly.

Increasingly, the joint questions of where, when, and how much to control an invasion have been tackled by the invasion control literature. Burnett et al. (2007) investigate the control of Miconia calvescens, an invasive plant in Hawaii with the potential to reduce biodiversity, soil cover, and water availability. Accounting for heterogeneous damages across the landscape, control costs, and spread dynamics, they find that resources for control should be increased relative to the existing expenditures, to reduce the invasion to a lower level and slow future spread and damages. Their model identifies optimal long-term densities of the invader across the landscape. Caplat et al. (2014) evaluate management strategies for slowing or containing tree invasions spreading from forestry plantations, accounting for heterogeneous habitat quality across the landscape. They find that total effort mattered more than the specific strategy, but that at the landscape scale, targeting peripheral stands was most effective. Sanchirico et al. (2010) study the effects of an invasive species on trade between regions and note substantial welfare gains from spatially optimized rather than uniform policies across locales, accounting for differences in productivity and risk. In the context of forests affected by a native pest, mountain pine beetle, Aadland et al. (2015) show that optimal harvesting of each patch depends on both the pest and tree stocks across the landscape, as the beetles disperse to areas with high tree stocks. Indeed, spatial policies are likely needed for efficiency in systems with spatial heterogeneity in benefits and costs or connectivity across the landscape, both of which are characteristic of invasions (Kroetz and Sanchirico 2015). 
To determine how to best target control efforts over time and space to minimize total costs and damages from a spreading invader, Epanchin-Niell and Wilen (2012) develop a spatial-dynamic bioeconomic model. Their study highlights several spatial strategies to reduce impacts, including reducing the length of the spreading invasion front (to reduce long-term control costs) and slowing or controlling the spread of an invasion in the direction of high-valued resources or large areas of uninvaded land. Control strategies also can optimally take advantage of natural spread barriers to enhance cost-efficiency of containment. The initial location of invasion establishment within a landscape also can affect long-term control strategies, as introduction occurring centrally within an invader's potential range can result in faster damage spread than incursions near the edge of the suitable range, thereby increasing the benefits of eradication.

Several spatial and temporal features of invasions also are relevant to optimizing invasion suppression and containment. When suppressing an invader population, Baker and Bode (2016) find that the rapidity of the program should depend on how the invader growth rate compares with the rate of diminishing returns to control expenditures. If growth rates are high or the returns to control investments diminish slowly, control should be completed more quickly, because faster control does not have a large cost penalty and gains can be realized from minimizing additional invader reproduction. When preventing spread into highvalued areas, Baker and Bode find that the optimal width of the control buffer increases as the population growth rate declines relative to the species' dispersal coefficient-conditions under which dispersal contributes more to population growth than local reproduction contributes.

Substantial debate has focused on the cost-effectiveness of targeting core versus outlier populations of an invader, with studies alternatively finding it optimal to target one or the other or both (Epanchin-Niell and Hastings 2010). Baker (2016) examines optimal management of an invasion that spreads through both local and long-distance dispersal and finds that when accounting for outlier populations having lower population spread and growth rates early on, targeting the source population is optimal, as this contributes more to slowing the spread and is more cost-effective. This finding would be further accentuated if the costs of detecting satellite populations were accounted for.
However, when (detected) outlier populations have grown to the point where they are contributing equally to spread and creating new populations, efforts should then target outlier populations over the main population.

The role of private decision-makers in invasion control

While substantial economic work has focused on topdown, centralized approaches for cost-effectively controlling invasions, the management and spread of invasive species often depend largely on the choices of many decision-makers across the landscape, from landowners deciding whether to suppress invasions on their land to individuals making decisions that affect the transport of invaders to new locations (such as through movement of infested firewood). Thus encouraging behavior that facilitates management of invasive species is key. A variety of tools are available for altering individuals' behavior, either by changing how they perceive an issue or by altering the consequences of a decision (Heberlein 2012; McKenzie-Mohr 2013; Wilson et al. 2016; Marzano et al. this issue). Such tools can be classified as either cognitive (information-based) or structural (consequencebased). Market-based and regulatory tools from economics typically focus on altering the consequences of a decision and hence are a subset of structural tools. Additional approaches that can be effective for achieving environmental outcomes include those that appeal to people's existing environmental values, invoke appropriate social cues to guide behavior (e.g., social norms), or make the desired behavior easier to perform (such as providing uninfested firewood at campsites to avoid transport of pests or making native plants more available at nurseries to encourage native plant use in gardens) (Wilson et al. 2016).

Among the tools considered by economists, regulation has been used to alter individual behavior by prohibiting or requiring particular behaviors. For example, noxious weed laws mandate control of certain plant species on landowners' properties and quarantines can prohibit the movement of risky goods to slow invasion spread. Regulations are sometimes quite effective, but in other cases they may have low compliance or even result in overlooked behavioral feedbacks, such as the development of illegal markets for banned goods. Regulations also impose costs of 
their own, as they limit behaviors that provide benefits to certain stakeholders (e.g., firewood transport). Although complete prohibition of invasion spread or mandated requirements for control may not be costefficient, without interventions private decision-makers (forest owners, recreationalists, homeowners) are likely to undercontrol invasions relative to what is best for society, because they typically incur only a small proportion of invader damages felt by society as a whole. Hence, when weighing the benefits of control relative to the costs of control, they undercontrol from a societal perspective.

Similar to the set of market and financial tools aimed at enhancing prevention efforts, a range of policies have been considered for reducing invasion spread and for incentivizing private management. These include taxes on invasion population levels or activities that transport invaders, subsidies for control efforts, tradable risk permits, assurance bonds, and insurance and indemnification funds, among others (Richards et al. 2008, 2010; Bekkerman et al. 2012; Goodwin and Piggott 2009; McDermott et al. 2013; McDermott 2015; Fenichel et al. 2014; Warziniack et al. 2013).

Focusing on reducing invasion spread, Warziniack et al. (2013) evaluate a visitation tax for reducing the movement of invasive species from invaded regions to uninvaded sites via recreational boating visits, focusing on the case of invasive mussel introduction into the northwestern United States. The authors find, however, that such a tax is unlikely to reduce mussel introduction likelihoods, as visitation rates are not very sensitive to a tax, though the tax could nonetheless provide revenue to help offset invasion damages. Moreover, if a tax were sufficient to reduce invasion likelihood, the lost revenue from reduced visitation would impose greater costs than the benefits from reduced invasion risk. Interactions such as these also would be relevant when evaluating market approaches for reducing forest invasion risk. McDermott (2015), on the other hand, finds that taxes on harvest and recreation aimed at reducing emerald ash borer spread and subsequent impacts could provide gains, but uncertainty in the system hinders setting the appropriate tax rates.

In addition to actively spreading invasive species, people affect invasion spread through their choice of invasion management. Invasions readily spread across jurisdictional boundaries, and thus forest and invasion management choices by one landowner can directly affect invasion levels and damages on other properties by affecting population levels and dispersal. Each landowner typically decides how intensively to manage an invader on his own property based on the damages he faces and his costs of management, without considering the additional benefits provided to his neighbors and the general public. As a result, he is likely to conduct too little invasion control from a societal perspective (Regev et al. 1976; Wilen 2007; Perrings et al. 2002).

This pervasive challenge to sufficient invasion control by private managers has received increasing attention by economists (e.g., Bhat et al. 1996; Jones et al. 2000; Grimsrud et al. 2008; Fenichel et al. 2014; Büyüktahtakın et al. 2013; Epanchin-Niell and Wilen 2015; Aadland et al. 2015; Liu and Sims 2016; Wilen 2007; Kovacs et al. 2014). Results show that cooperative or centralized management of an invasion is generally needed to achieve socially optimal levels. Cooperative control can arise both in practice and in theory as landowners seek to internalize the externalities generated from invasion spread (Epanchin-Niell et al. 2010; Fiege 2005; Hershdorfer et al. 2007; Wilen 2007; Bhat and Huffaker 2007). For example, landowners may pay their neighbors to increase their management efforts, agree to share the costs of control, or simply coordinate their efforts in a beneficial way to minimize spillover effects. Wilen (2007) suggests that a series of bilateral management agreements could arise among neighbors and substantially reduce the social costs associated with invasion spread. Bhat et al. (1996) explore the undercontrol of nuisance beaver populations under decentralized management, and Bhat and Huffaker (2007) propose a self-reinforcing payment strategy among neighbors that would induce socially optimal levels of control effort. In the context of invasion spread across a series of adjacent agricultural or timber producers, Liu and Sims (2016) predict that invasions will spread more quickly in landscapes with many smaller producers than in those with fewer larger producers, because larger producers have greater incentives to control the invader; however, a series of transfer payments among producers could enhance invasion control.

Localized coordination of invasion control through a cooperative management district also could reduce landscape-level invasion impacts. Epanchin-Niell and Wilen (2015) model an invasive species spreading 
across a landscape consisting of many independent land managers and find that coordinated control, funded by voluntary contributions from land managers near to the invasion, can provide substantial economic gains. They consider a funding mechanism in which elicited contributions are only collected (and control implemented) if the total contributions are sufficient to fund the proposed control activity. This approach-a pivot point mechanism-has been shown to induce socially optimal contributions in other contexts. The authors find that under cost conditions where coordinated control may provide the largest gains relative to independent management, cooperative management also may be easiest to achieve, supporting that mechanisms such as invasion control districts could improve forest invasion management outcomes, particularly if transaction costs can be minimized.

Decentralized management poses challenges at municipal jurisdictional scales as well. Kovacs et al. (2014) model the independent management of emerald ash borer, an invasive forest pest, by 17 different municipal jurisdictions. Each jurisdiction determines the number of trees in public ownership to treat and remove over time to maximize benefits of surviving trees across their public and private lands, subject to municipal budget constraints. The authors account for the spatial dynamics of pest spread and variation in pest damages across the landscape and find that independent jurisdictional management leads to far worse outcomes than if the municipalities were to pool resources and optimally coordinate control across the region. A lack of public access to trees on private lands also hinders effective management.

In some cases, pest dynamics can lead to competing incentives for private land managers, as in the case of mountain pine beetle, a native forest pest. Local timber harvest induces both benefits and costs to other land managers: harvest reduces beetle reproduction but also increases its migration to other properties (Aadland et al. 2015). Private harvest decisions therefore affect the supply of forest ecosystem services across the landscape, with incentives to both under- and overharvest from a landscape-wide perspective. In this case the two opposing tendencies generally offset each other, leading to relatively optimal levels of control by land managers, but the authors find that in systems with other rates of dispersal and resource growth, uncoordinated private timber harvest may result in high social costs.
In general, higher rates of pest dispersal among properties reduces private control incentives. In addition, Fenichel et al. (2014) find that increased control by one landowner enhances the benefits of control on neighboring lands - a pattern that leads to undercontrol by private landowners in spatially heterogeneous landscapes. While the authors find that a series of localized transactions among neighbors could enhance invasion control outcomes, they find that a tax on invader populations could actually decrease private invasion control in some situations by reducing property values and hence the incentives to control. This highlights some of the complexities of market policy design for invasion management.

A program proposed to manage wind-borne diseases in agriculture also may be relevant to forest invasion management. Bekkerman et al. (2012) examine a check-off program for at-risk commodities-a mandatory collection of funds from producers to help pay for private control efforts during an infestation. The collected funds would be allocated to producers incurring invasion, as well as those nearby, to encourage control of outbreaks and to prevent spread to larger areas. The authors find that the fund collection would not induce substantial economic costs but would reduce costs from an invasion outbreak by enhancing control and reducing spread. They also note that this approach encourages reporting of outbreaks by producers. On the other hand, approaches such as tradable permits and taxes on invaded properties are likely to require substantial external monitoring, because producers may underreport invasion levels to avoid being taxed or penalized.

\section{Decision-making under uncertainty}

Uncertainty is a critical issue in economic analyses of invasion management, as most aspects of both the ecological and economic system are highly uncertain. Studies have taken various approaches to addressing system uncertainties. Some have set aside the issue of uncertainty with the aim to gain basic understanding of managing a complex social-ecological system by focusing on simpler deterministic representations of the problem. Such studies nonetheless often use sensitivity analyses to evaluate the influence of uncertain inputs or to understand how optimal policies may vary across systems that have different underlying characteristics. While general understanding of 
management strategies can be gained by focusing on deterministic processes and assuming known parameters and processes, application of bioeconomic analyses to specific systems generally requires more explicit consideration of process and parameter uncertainty and the robustness of management choices. For example, the robustness of market-based policies for incentivizing desired levels of private invasion control generally have found that existing economic uncertainty substantially hinders effective application of these tools.

Economic analyses have tackled the challenge of decision-making under known or severe uncertainty using a diversity of approaches. Models most commonly incorporate uncertainty by assuming known distributions of uncertain parameters and optimizing the expected outcome-the probability weighted average across potential outcomes that arise from the uncertainty. This is termed "expected utility optimization" and is the typical approach of many economic analyses. Other studies have instead modeled the uncertainty regarding beliefs about the true value of system parameters and allowed for the beliefs and the uncertainty surrounding them to be updated over time, typically using Bayesian approaches (e.g., Haight and Polasky 2010; Rout et al. 2009, 2014; Chadès et al. 2011; Springborn 2014; Burgman et al. 2010). These studies optimize investments, explicitly accounting for the value of reduced uncertainty from those investments for improving management. Value of information also has been incorporated into other decision models for invasion management (Moore et al. 2011), and real options models consider the optimal timing of management investments accounting for how uncertainty about invasion damages may be alleviated over time (e.g., Marten and Moore 2011; Saphores and Shogren 2005; Sims and Finnoff 2013). Experience-weighted attraction learning models have been considered for improving invasion management by reducing uncertainty over time (Eiswerth and van Kooten 2007).

Although substantial invasion research has assumed known distributions of uncertainty, in reality, uncertainty about ecological and economic aspects of bioinvasions can be severe and elude distribution specification. To deal with severe uncertainty, some studies have simply used sensitivity analyses to explore how changes in underlying model assumptions affect the optimal management choice (e.g.,
Epanchin-Niell et al. 2012) or how the economic outcomes of a selected policy depend on the model assumptions (e.g., Leung et al. 2014; Epanchin-Niell et al. 2012, 2014). Others have employed approaches specifically developed for robust decision-making under extreme uncertainty, including informationgap theory, maximin criterion, and minimax regret strategy (Thompson et al. 2012; Mehta et al. 2010; Polasky et al. 2011). These approaches generally aim to select policies that will avoid some of the worst outcomes that could arise under uncertainty. Information-gap theory, for example, selects the policy that achieves an acceptable outcome across the widest range of potential uncertainty (Ben-Haim 2006), essentially addressing the question of how much uncertainty can be tolerated before the decision would change. The approach can account for multiple forms of uncertainty simultaneously (Regan et al. 2005; BenHaim 2006) and has been applied to designing cargo inspections to prevent invader introductions (Moffitt et al. 2008), deciding when to declare successful eradication of an invader (Rout et al. 2009), and controlling invasive species' spread across the landscape (Carrasco et al. 2010a). The maximin (also referred to as minimax) approach, on the other hand, selects the invasion management policy that performs the least poorly across all potential realizations of an uncertain future (i.e., the policy under which the worst possible outcome is the least bad) (Thompson et al. 2012; Mehta et al. 2010) and has been applied to developing a list of priority pests (Moffitt and Osteen 2006). The minimax regret approach minimizes the potential regret associated with a policy choice by selecting the policy that minimizes the difference between the best and worst potential outcomes of the decision under realizations of uncertainty (Thompson et al. 2012; Mehta et al. 2010).

Other methods for incorporating uncertainty include "fuzzy sets" that account for multiple types of uncertainty and the challenges in quantifying them (Eiswerth and van Kooten 2002). Horan et al. (2002) use surprise functions that include measures of how surprised the decision-maker would be to experience a particular outcome given selected management choices. Multiattribute decision analysis also has been proposed for determining acceptable invasion management strategies given the uncertain outcomes of invasion management, the prevalence of multiple and conflicting objectives, and the many stakeholders with 
differing values and views on the functioning of the system (Maguire 2004). Such structured decisionmaking provides a systematic means for eliciting objectives, values, and system understanding, but ultimately could use one of the many approaches described here to identify potential solutions for a particular decision context.

\section{Looking forward}

The research described above highlights the complexity of invasive species management, the substantial societal trade-offs involved in decision-making and policy design, and the difficulty in designing one-sizefits-all policies. Nonetheless, the research identifies some key implications for invasion management, including the following:

- The choices of prevention, detection, and control are interdependent, and managers should evaluate the cost-effectiveness of options at each stage when developing policies.

- Control choices are rarely all or nothing. The choice generally is how much to prevent and control, rather than whether to prevent or control.

- The cost-effectiveness of investments at a location ideally should be evaluated by comparing the expected long-term damage reductions with the costs of interventions. Although both of these are difficult to quantify, ignoring either is incorrect, as it assumes a value of zero.

- Policies can have counterproductive consequences if potential feedbacks are not taken into account. Just as adjusting one component of an ecological system can have cascading effects, policies can induce unintended responses in the social system, such as incentivizing undesirable behavioral responses or triggering risk-increasing feedbacks across economic sectors.

- Optimal investments in invasion control depend on the rate of invasion growth, potential magnitude and extent of damages, and the costs and effectiveness of control options.

- Surveillance for early detection provides larger gains when introduction rates are high, survey methods are effective and inexpensive, and early detection of an invader can substantially reduce damages over the long term.
- Spatial strategies for controlling invasion spread can reduce long-term damages by protecting highvalue resources or large areas of at-risk land.

- Strategies that coordinate invasion management across space, stakeholders, and landowners can substantially improve outcomes, although high transaction costs reduce net benefits.

In addition, the increasing body of work on costeffectively managing biological invasion has developed approaches for analysis and findings that can be applied to specific management applications and highlights several overarching areas deserving of further research attention.

Further evaluation of tools for altering behaviors that affect invasion risk

Economics provides important frameworks for evaluating and designing invasion management policies and incentive mechanisms. In addition to examination of market and financial tools, improved understanding of behavioral science approaches for altering behavior and choices that drive invasion processes is needed. Behavioral science tools may be particularly important for reducing invasion spread, enhancing early detection of new invasions by the public, and increasing private control efforts. Investments in implementing these tools can be evaluated within a bioeconomic framework as their costs and effectiveness are better understood.

More comprehensive consideration of the interconnectedness of control and management decisions across the stages of an invasion

The choices of prevention, surveillance, and control are highly interdependent. For example, early detection has value if it will reduce the costs of an invasion relative to the absence of surveillance, and this depends on anticipated control or mitigation actions. Similarly, the optimal amount of prevention depends on the anticipated damages from introduction and hence the expected intensities of surveillance and postdetection control. For instance, greater emphasis on prevention strategies may be optimal for damaging species that are difficult to detect in the environment, especially as low detection rates will likely also hinder subsequent control efforts. Thus policy decisions 
across the safeguarding continuum cannot be made in isolation and demand further investigation.

More holistic evaluation of management policies within a social-ecological framework

Evaluation of policies focused on invasions or other challenges should more broadly consider how such policies influence not only biological invasion impacts but also other societal objectives and ecological outcomes. When invasion or policy impacts are large enough, their influence can extend across economic sectors, with sometimes unexpected consequences (e.g., tariffs increasing invasion susceptibility by altering domestic production; Costello and McAusland 2003). Policies also can interact in ways that should be taken into account in policy design (e.g., counterproductive interactions among invasion and agricultural policies; Acquaye et al. 2005). Similarly, far-reaching ecological consequences of invasion management also can arise (Hulme 2006). More holistic evaluation of the social-ecological system and its institutions can be important.

Increased analysis of how policies might interact across multiple invaders

Policies can affect multiple invaders simultaneously, and feedback can occur across invaders as well. For example, pathway-focused prevention efforts (e.g., preborder control interventions) that reduce entry of multiple (known and unknown) invaders may provide greater benefits than prevention efforts focused on exclusion of a single species. Single-species focused analyses may overlook the cobenefits of such policies. Also, the prior establishment of an invader in a system may alter the damages posed by subsequent invaders. These have implications for policy and management design.

Continued accounting for uncertainty in policy analysis

Importantly, our understanding of invasion risk and how it varies across pathways, as well as how interventions may alter that risk, remains highly uncertain despite the increasing research examining bioinvasions. The combination of difficulty in predicting invasion likelihood and damages ex ante and in linking specific invasions to particular pathways or entities ex post hinders application of typical economic tools for cost-efficiently reducing invasion risk. Efforts are needed to both reduce uncertainty (through improved ecosystem valuation, risk predictions, and so forth) and improve decision-making in the face of that uncertainty. Adaptive management of biological invasions, in which interventions are updated over time as key ecological and economic uncertainties are reduced, is ripe for economic analysis and application. In addition, efforts to coordinate and communicate lessons learned across invader incursions could speed the adaptation process to improve management over time.

\section{Conclusion}

While some economic analyses have focused specifically on forest invasions, substantial understanding also can be gained from studies of agricultural pests and invaders in other systems, as described in this article. Such studies provide insights into analytical approaches, general principles of invasion management, social-ecological feedbacks affecting invasion outcomes and management, and how invasion characteristics may affect optimal management approaches.

Economic research on invasive species has blossomed over the past decades, with substantial focus on how to cost-effectively manage biological invasion risk, recognizing the trade-offs involved in reducing invasion impacts and the key role of human activities in driving invasions. Economic research has focused largely on estimating impacts of invasive species, identifying optimal prevention and control strategies, and evaluating market-based approaches for reducing invasion impacts. Policy evaluation needs to account for both the direct and opportunity costs of policies, recognizing that resources allocated to invasion control are being diverted from alternative uses and that policies for controlling or preventing invasions typically impose other societal costs. In addition, costs and benefits often are borne by different groups, further challenging policy design. Economists and ecologists need to continue to work together to improve invasion management. In addition, increased communication and collaboration among researchers and decisionmakers are needed to better translate existing research 
findings into policy-relevant guidance and to identify specific policy needs to drive future research directions.

Open Access This article is distributed under the terms of the Creative Commons Attribution 4.0 International License (http:// creativecommons.org/licenses/by/4.0/), which permits unrestricted use, distribution, and reproduction in any medium, provided you give appropriate credit to the original author(s) and the source, provide a link to the Creative Commons license, and indicate if changes were made.

\section{References}

Aadland D, Sims C, Finnoff D (2015) Spatial dynamics of optimal management in bioeconomic systems. Comput Econ 45(4):545-577

Acquaye AK, Alston JM, Lee H, Sumner DA (2005) Economic consequences of invasive species policies in the presence of commodity programs: theory and application to citrus canker. Appl Econ Perspect Policy 27(3):498-504

Ameden HA, Cash SB, Zilberman D (2007) Border enforcement and firm response in the management of invasive species. J Agric Appl Econ 39:35-36

Ameden HA, Boxall PC, Cash SB, Vickers DA (2009) An agent-based model of border enforcement for invasive species management. Can J Agric Econ 57(4):481-496

Andersen MC, Adams H, Hope B, Powell M (2004) Risk assessment for invasive species. Risk Anal 24(4):787-793

Baker CM (2016) Target the source: optimal spatiotemporal resource allocation for invasive species control. Conserv Lett. doi: $10.1111 /$ conl.12236

Baker CM, Bode M (2016) Placing invasive species management in a spatiotemporal context. Ecol Appl 26(3):712-725

Barbier EB, Shogren JF (2004) Growth with endogenous risk of biological invasion. Econ Inq 42:587-601

Bekkerman A, Piggott NE, Goodwin BK, Jefferson-Moore K (2012) A market-based mitigation program for wind-borne diseases. Agric Resour Econ Rev 41(2): 175

Ben-Haim Y (2006) Information-gap decision theory: decisions under severe uncertainty. Academic Press, Oxford

Berec L, Kean JM, Epanchin-Niell R, Liebhold AM, Haight RG (2015) Designing efficient surveys: spatial arrangement of sample points for detection of invasive species. Biol Invasions 17(1):445-459

Bhat MG, Huffaker RG (2007) Management of a transboundary wildlife population: a self-enforcing cooperative agreement with renegotiation and variable transfer payments. J Environ Econ Manag 53(1):54-67

Bhat MG, Huffaker RG, Lenhart SM (1996) Controlling transboundary wildlife damage: modeling under alternative management scenarios. Ecol Model 92(2):215-224

Blackwood JC, Berec L, Yamanaka T et al (2012) Bioeconomic synergy between tactics for insect eradication in the presence of Allee effects. Proc $R$ Soc B Biol Sci 279:2807-2815
Bogich TL, Liebhold AM, Shea K (2008) To sample or eradicate? A cost minimization model for monitoring and managing an invasive species. J Appl Ecol 45(4):1134-1142

Born W, Rauschmayer F, Bräuer I (2005) Economic evaluation of biological invasions: a survey. Ecol Econ 55:321-336

Boyd J, Epanchin-Niell R, Siikamäki J (2015) Conservation planning: a review of return on investment analysis. Rev Environ Econ Policy 9:23-42

Burgman MA, Wintle BA, Thompson CA, Moilanen A, Runge MC, Ben-Haim Y (2010) Reconciling uncertain costs and benefits in Bayes nets for invasive species management. Risk Anal 30(2):277-284

Burnett K, Kaiser B, Roumasset J (2007) Invasive species control over space and time: Miconia calvescens on Oahu, Hawaii. J Agric Appl Econ 39:125

Burnett KM, D'Evelyn S, Kaiser BA, Nantamanasikarn P, Roumasset JA (2008) Beyond the lamppost: optimal prevention and control of the brown tree snake in Hawaii. Ecol Econ 67:66-74

Büyüktahtakın IEE, Feng Z, Frisvold G, Szidarovszky F (2013) Invasive species control based on a cooperative game. Appl Math 4(10):54

Cacho OJ, Hester SM (2011) Deriving efficient frontiers for effort allocation in the management of invasive species. Aust J Agric Resour Econ 55:72-89

Cacho OJ, Spring D, Hester S et al (2010) Allocating surveillance effort in the management of invasive species: a spatially-explicit model. Environ Modell Softw 25:444-454

Caplat P, Hui C, Maxwell BD, Peltzer DA (2014) Cross-scale management strategies for optimal control of trees invading from source plantations. Biol Invasions 16(3):677-690

Carrasco L, Baker R, Macleod A et al (2010a) Optimal and robust control of invasive alien species spreading in homogeneous landscapes. J R Soc Interface 7(44):529-540

Carrasco L, Mumford J, MacLeod A, Knight J, Baker R (2010b) Comprehensive bioeconomic modelling of multiple harmful non-indigenous species. Ecol Econ 69:1303-1312

Chadès I, Martin TG, Nicol S et al (2011) General rules for managing and surveying networks of pests, diseases, and endangered species. Proc Natl Acad Sci USA 108:8323-8328

Chen C, Epanchin-Niell R, Haight RG (under review) Optimal inspection of imports to prevent invasive pest introduction. Risk Anal

Costello C, McAusland C (2003) Protectionism, trade, and measures of damage from exotic species introductions. Am J Agric Econ 85:964-975

D’Evelyn ST, Tarui N, Burnett K et al (2008) Learning-bycatching: uncertain invasive-species populations and the value of information. J Environ Manag 89:284-292

Donlan CJ, Luque GM, Wilcox C (2015) Maximizing return on investment for island restoration and species conservation. Conserv Lett 8:171-179

Eiswerth ME, Johnson WS (2002) Managing nonindigenous invasive species: insights from dynamic analysis. Environ Resour Econ 23:319-342

Eiswerth ME, van Kooten GC (2002) Uncertainty, economics, and the spread of an invasive plant species. Am J Agric Econ 84:1317-1322 
Eiswerth ME, van Kooten GC (2007) Dynamic programming and learning models for management of a nonnative species. Can J Agric Econ 55:485-498

Eiswerth M, Epanchin-Niell R, Rollins K, Taylor MH (2016) Economic modeling and the management of exotic annual Bromus species: accounting for ecosystem dynamics, ecological thresholds, and spatial interdependencies. In: Germino MJ, Chambers JC, Brown CS (eds) Exotic bromegrasses in arid and semiarid ecosystems of the western US. Springer, Cham, pp 429-456

Epanchin-Niell RS, Hastings A (2010) Controlling established invaders: integrating economics and spread dynamics to determine optimal management. Ecol Lett 13:528-541

Epanchin-Niell R, Liebhold AM (2015) Benefits of invasion prevention: effect of time lags, spread rates, and damage persistence. Ecol Econ 116:143-146

Epanchin-Niell RS, Wilen JE (2012) Optimal spatial control of biological invasions. J Environ Econ Manag 63:260-270

Epanchin-Niell RS, Wilen JE (2015) Individual and cooperative management of invasive species in human-mediated landscapes. Am J Agric Econ 97(1):180-198

Epanchin-Niell R, Hufford M, Aslan C, Sexton J, Port J, Waring $\mathrm{T}$ (2010) Controlling invasive species in complex social landscapes. Front Ecol Environ 8(4):210-216

Epanchin-Niell RS, Haight RG, Berec L et al (2012) Optimal surveillance and eradication of invasive species in heterogeneous landscapes. Ecol Lett 15:803-812

Epanchin-Niell RS, Brockerhoff EG, Kean JM et al (2014) Designing cost-efficient surveillance for early detection and control of multiple biological invaders. Ecol Appl 24:1258-1274

Fenichel EP, Richards TJ, Shanafelt DW (2014) The control of invasive species on private property with neighbor-toneighbor spillovers. Environ Resour Econ 59(2):231-255

Fernandez L (2011) Economic incentives to prevent aquatic invasive species in wetlands. Can J Agric Econ 59:281-293

Fernandez L, Sheriff G (2013) Optimal border policies for invasive species under asymmetric information. Environ Resour Econ 56(1):27-45

Fiege M (2005) The weedy West: mobile nature, boundaries, and common space in the Montana landscape. Western Hist Q 36(1):22-47

Finnoff D, Shogren JF, Leung B et al (2005) Risk and nonindigenous species management. Rev Agric Econ 27:475-482

Finnoff D, Shogren J, Leung B, Lodge D (2007) Take a risk: preferring prevention over control of biological invaders. Ecol Econ 62:216-222

Finnoff D, McIntosh C, Shogren JF, Sims C, Warziniack T (2010a) Invasive species and endogenous risk. Annu Rev Resour Econ 2(1):77-100

Finnoff D, Potapov A, Lewis MA (2010b) Control and the management of a spreading invader. Resour Energy Econ 32:534-550

Goodwin BK, Piggott NE (2009) Spatiotemporal modeling of Asian citrus canker risks: implications for insurance and indemnification fund models. Am J Agric Econ 91(4):1038-1055

Gren I-M (2008) Economics of alien invasive species management-choices of targets and policies. Boreal Environ Res $13: 17-32$
Grimsrud KM, Chermak JM, Hansen J et al (2008) A two-agent dynamic model with an invasive weed diffusion externality: an application to yellow starthistle (Centaurea solstitialis L.) in New Mexico. J Environ Manag 89:322-335

Haight RG, Polasky S (2010) Optimal control of an invasive species with imperfect information about the level of infestation. Resour Energy Econ 32(4):519-533

Haight RG, Homans FR, Horie T, Mehta SV, Smith DJ, Venette RC (2011) Assessing the cost of an invasive forest pathogen: a case study with oak wilt. Environ Manag 47:506-517

Hauser C, McCarthy M (2009) Streamlining "search and destroy": cost-effective surveillance for invasive species management. Ecol Lett 12:683-692

Heberlein TA (2012) Navigating environmental attitudes. Conserv Biol 26(4):583-585

Hershdorfer ME, Fernandez-Gimenez ME, Howery LD (2007) Key attributes influence the performance of local weed management programs in the southwest United States. Rangel Ecol Manag 60:225-234

Hester SM, Cacho OJ (2017) The contribution of passive surveillance to invasive species management. Biol Invasions 19(3):737-748

Holden MH, Nyrop JP, Ellner SP (2016) The economic benefit of time-varying surveillance effort for invasive species management. J Appl Ecol 53:712-721

Holmes TP, Aukema JE, Von Holle B et al (2009) Economic impacts of invasive species in forests. Ann NY Acad Sci 1162:18-38

Holmes TP, Aukema J, Englin J et al (2014) Economic analysis of biological invasions in forests. In: Kant S, Alavalapati J (eds) Handbook of forest resource economics. Earthscan (Routledge), New York, pp 369-386

Homans F, Horie T (2011) Optimal detection strategies for an established invasive pest. Ecol Econ 70:1129-1138

Horan RD, Lupi F (2005) Tradeable risk permits to prevent future introductions of invasive alien species into the Great Lakes. Ecol Econ 52(3):289-304

Horan RD, Perrings C, Lupi F, Bulte E (2002) Biological pollution prevention strategies under ignorance: the case of invasive species. Am J Agric Econ 84:1303-1310

Horie T, Haight RG, Homans FR et al (2013) Optimal strategies for the surveillance and control of forest pathogens: a case study with oak wilt. Ecol Econ 86:78-85

Hulme PE (2006) Beyond control: wider implications for the management of biological invasions. J Appl Ecol 43:835-847

Hulme PE (2009) Trade, transport and trouble: managing invasive species pathways in an era of globalization. $\mathrm{J}$ Appl Ecol 46(1):10-18

Hulme PE (2012) Weed risk assessment: a way forward or a waste of time? J Appl Ecol 49:10-19

Jones KR, Corona JP (2008) An ambient tax approach to invasive species. Ecol Econ 64(3):534-541

Jones RE, Vere DT, Campbell MH (2000) The external costs of pasture weed spread: an economic assessment of serrated tussock control. Agric Econ 22(1):91-103

Kaiser BA, Burnett KM (2010) Spatial economic analysis of early detection and rapid response strategies for an invasive species. Resour Energy Econ 32:566-585 
Keller RB, Lodge DM, Finnoff DC (2007) Risk assessment for invasive species produces net bioeconomic benefits. Natl Acad Sci USA 104:203-207

Kim CS, Lubowski RN, Lewandrowski J, Eiswerth ME (2006) Prevention or control: optimal government policies for invasive species management. Agric Resour Econ Rev 35:29-40

Kizlinski ML, Orwig DA, Cobb RC et al (2002) Direct and indirect ecosystem consequences of an invasive pest on forests dominated by eastern hemlock. J Biogeogr 29:1489-1503

Knowler D, Barbier E (2005) Importing exotic plants and the risk of invasion: are market-based instruments adequate? Ecol Econ 52(3):341-354

Kovacs KF, Haight RG, McCullough DG, Mercader RJ, Siegert NW, Liebhold AM (2010) Cost of potential emerald ash borer damage in US communities, 2009-2019. Ecol Econ 69(3):569-578

Kovacs K, Václavík T, Haight RG, Pang A, Cunniffe NJ, Gilligan CA, Meentemeyer RK (2011a) Predicting the economic costs and property value losses attributed to sudden oak death damage in California (2010-2020). J Environ Manag 92:1292-1302

Kovacs KF, Mercader RJ, Haight RG, Siegert NW, McCullough DG, Liebhold AM (2011b) The influence of satellite populations of emerald ash borer on projected economic damage in U.S. communities, 2010-2020. J Environ Manag 92:2170-2181

Kovacs KF, Haight RG, Mercader RJ, McCullough DG (2014) A bioeconomic analysis of an emerald ash borer invasion of an urban forest with multiple jurisdictions. Resour Energy Econ 36(1):270-289

Kroetz K, Sanchirico JN (2015) The bioeconomics of spatialdynamic systems in natural resource management. Annu Rev Resour Econ 7:189-207

Leung B, Lodge DM, Finnoff D, Shogren JF, Lewis MA, Lamberti G (2002) An ounce of prevention or a pound of cure: bioeconomic risk analysis of invasive species. Proc Roy Soc B-Biol Sci 269:2407-2413

Leung B, Finnoff D, Shogren JF, Lodge D (2005) Managing invasive species: rules of thumb for rapid assessment. Ecol Econ 55:24-36

Leung B, Roura-Pascual N, Bacher S, Heikkilä J, Brotons L, Burgman MA, Dehnen-Schmutz K, Essl E, Hulme PE, Richardson DM, Sol D, Vilà M (2012) TEASIng apart alien-species risk assessments: a framework for best practices. Ecol Lett 15:1475-1493

Leung B, Springborn MR, Turner JA et al (2014) Pathway-level risk analysis: the net present value of an invasive species policy in the US. Front Ecol Environ 12:273-279

Liebhold AM, Brockerhoff EG, Garrett LJ et al (2012) Live plant imports: the major pathway for forest insect and pathogen invasions of the US. Front Ecol Environ 10:135-143

Liebhold AM, Berec L, Brockerhoff EG, Epanchin-Niell RS, Hastings A, Herms DA, Kean JM, McCullough DG, Suckling DM, Tobin PC, Yamanaka T (2016) Eradication of invading insect populations: from concepts to applications. Annu Rev Entomol 61:335-352

Lieli RP, Springborn M (2012) Closing the gap between risk estimation and decision making: efficient management of trade-related invasive species risk. Rev Econ Stat 95:632-645

Liu Y, Sims C (2016) Spatial-dynamic externalities and coordination in invasive species control. Resour Energy Econ 44:23-38

Lodge DM, Williams S, MacIsaac HJ, Hayes KR, Leung B, Reichard S, Mack RN, Moyle PB, Smith M, Andow DA, Carlton JT (2006) Biological invasions: recommendations for US policy and management. Ecol Appl 16(6):2035-2054

Lovett GM, Weiss M, Liebhold AM, Holmes TP, Leung B, Lambert KF, Orwig DA, Campbell FT, Rosenthal J, McCullough DG, Wildova R, Ayres MP, Canham CD, Foster DR, LaDeau SL, Weldy T (2016) Nonnative forest insects and pathogens in the United States: impacts and policy options. Ecol Appl 26:1437-1455

Maguire LA (2004) What can decision analysis do for invasive species management? Risk Anal 24(4):859-868

Marbuah G, Gren I-M, McKie B (2014) Economics of harmful invasive species: a review. Diversity 6:500-523

Margolis M, Shogren JF, Fischer C (2005) How trade politics affect invasive species control. Ecol Econ 52:305-313

Marten AL, Moore CC (2011) An options based bioeconomic model for biological and chemical control of invasive species. Ecol Econ 70(11):2050-2061

McAusland C, Costello C (2004) Avoiding invasives: traderelated policies for controlling unintentional exotic species introductions. J Environ Econ Manag 48:954-977

McDermott S (2015) Optimal regulation of invasive species long-range spread: a general equilibrium approach. BE J Econ Anal Poli 15(4):1731-1752

McDermott SM, Irwin RE, Taylor BW (2013) Using economic instruments to develop effective management of invasive species: insights from a bioeconomic model. Ecol Appl 23(5):1086-1100

McKenzie-Mohr D (2013) Fostering sustainable behavior: an introduction to community-based social marketing. New Society Publishers, Gabriola Island

Mehta SV, Haight RG, Homans FR et al (2007) Optimal detection and control strategies for invasive species management. Ecol Econ 61:237-245

Mehta SV, Haight RG, Homans FR (2010) Decisionmaking under risk in invasive species management: risk management theory and applications. In: Pye JM, Rauscher HM, Sands Y, Lee DC, Beatty JS (tech eds) Advances in threat assessment and their application to forest and rangeland management. Gen. Tech. Rep. PNW-GTR-802. US Department of Agriculture, Forest Service, Pacific Northwest and Southern Research Stations, Portland, Oregon, pp 445-468

Mérel PR, Carter CA (2008) A second look at managing import risk from invasive species. J Environ Econ Manag 56:286-290

Moffitt J, Osteen C (2006) Prioritizing invasive species: threats under uncertainty. Agric Resour Econ Rev 35:41-51

Moffitt LJ, Stranlund JK, Osteen CD (2008) Robust detection protocols for uncertain introductions of invasive species. J Environ Manag 89(4):293-299

Moore AL, McCarthy MA (2016) Optimizing ecological survey effort over space and time. Methods Ecol Evol 7(8):891-899 
Moore JL, Rout TM, Hauser CE, Moro D, Jones M, Wilcox C, Possingham HP (2010) Protecting islands from pest invasion: optimal allocation of biosecurity resources between quarantine and surveillance. Biol Conserv 143:1068-1078

Moore JL, Runge MC, Webber BL et al (2011) Contain or eradicate? Optimizing the management goal for Australian acacia invasions in the face of uncertainty. Divers Distrib 17:1047-1059

Moser WK, Barnard EL, Billings RF, Crocker SJ, Dix ME, Gray AN, Ice GG, Kim MS, Reid R, Rodman SU, McWilliams WH (2009) Impacts of nonnative invasive species on US forests and recommendations for policy and management. J Forest 107(6):320-327

Murdoch W, Polasky S, Wilson KA et al (2007) Maximizing return on investment in conservation. Biol Conserv 139:375-388

Olson L (2006) The economics of terrestrial invasive species: a review of the literature. Agric Resour Econ Rev 35:178-194

Olson L, Roy S (2002) The economics of controlling a stochastic biological invasion. Am J Agric Econ 84:1311-1316

Olson L, Roy S (2005) On prevention and control of an uncertain biological invasion. Rev Agric Econ 27:491-497

Olson L, Roy S (2008) Controlling a biological invasion: a nonclassical dynamic economic model. Econ Theory 36:453-469

Perrings C, Williamson M, Barbier EB, Delfino D, Dalmazzone S, Shogren J, Simmons P, Watkinson A (2002) Biological invasion risks and the public good: an economic perspective. Conserv Ecol 6(1):1

Polasky S (2010) A model of prevention, detection, and control for invasive species. In: Perrings C, Mooney H, Williamson $\mathrm{M}$ (eds) Bioinvasions and globalization. Oxford University Press, Oxford, pp 100-107

Polasky S, Carpenter SR, Folke C, Keeler B (2011) Decisionmaking under great uncertainty: environmental management in an era of global change. Trends Ecol Evol 26(8):398-404

Pyšek P, Lambdon PW, Arianoutsou M et al (2009) Alien vascular plants of Europe. Handbook of Alien Species in Europe. Springer, New York, pp 43-61

Regan HM, Ben-Haim Y, Langford B, Wilson WG, Lundberg P, Andelman SJ, Burgman MA (2005) Robust decisionmaking under severe uncertainty for conservation management. Ecol Appl 15(4):1471-1477

Regan TJ, McCarthy MA et al (2006) Optimal eradication: when to stop looking for an invasive plant. Ecol Lett 9(7):759-766

Regan TJ, Chadès I, Possingham HP (2011) Optimally managing under imperfect detection: a method for plant invasions. J Appl Ecol 48:76-85

Regev U, Gutierrez AP, Feder G (1976) Pests as a common property resource: a case study of alfalfa weevil control. Am J Agric Econ 58(2):186-197

Reichard SH, White P (2001) Horticulture as a pathway of invasive plant introductions in the United States. Bioscience 51(2):103-113

Richards TJ, Eaves J, Manfredo M, Naranjo SE, Chu C-C, Henneberry TJ (2008) Spatial-temporal model of insect growth, diffusion and derivative pricing. Am J Agric Econ 90(4):962-978
Richards TJ, Ellsworth P, Tronstad R, Naranjo S (2010) Marketbased instruments for the optimal control of invasive insect species: B. tabaci in Arizona. J Agric Resour Econ 35(3):349-367

Roques A, Rabitsch W, Rasplus J-Y et al (2009) Alien terrestrial invertebrates of Europe. Handbook of Alien Species in Europe. Springer, New York, pp 63-79

Rosenberger RS, Bell LA, Champ PA et al (2012) Nonmarket economic values of forest insect pests: an updated literature review. Gen Tech Rep RMRS-GTR-275WWW. US Department of Agriculture, Forest Service, Rocky Mountain Research Station, Fort Collins, CO

Rout TM, Thompson CJ, McCarthy MA (2009) Robust decisions for declaring eradication of invasive species. J Appl Ecol 46(4):782-786

Rout TM, Moore JL, Possingham HP, McCarthy MA (2011) Allocating biosecurity resources between preventing, detecting, and eradicating island invasions. Ecol Econ 71:54-62

Rout TM, Moore JL, McCarthy MA (2014) Prevent, search or destroy? A partially observable model for invasive species management. J Appl Ecol 51:804-813

Sanchirico J, Albers H, Fischer C et al (2010) Spatial management of invasive species: pathways and policy options. Environ Resour Econ 45:517-535

Saphores J-D, Shogren J (2005) Managing exotic pests under uncertainty: optimal control actions and bioeconomic investigations. Ecol Econ 52:327-339

Schmidt JP, Springborn M, Drake JM (2012) Bioeconomic forecasting of invasive species by ecological syndrome. Ecosphere 3:1-19

Settle C, Shogren TD, Crocker JF (2002) On the joint determination of biological and economic systems. Ecol Econ 42:301-311

Sharov AA, Liebhold AM (1998) Bioeconomics of managing the spread of exotic pest species with barrier zones. Ecol Appl 8:833-845

Simberloff D (2011) How common are invasion-induced ecosystem impacts? Biol Invasions 13(5):1255-1268

Simberloff D, Parker IM, Windle PN (2005) Introduced species policy, management, and future research needs. Front Ecol Environ 3(1):12-20

Sims C (2011) Optimal timing of salvage harvest in response to a stochastic infestation. Nat Resour Model 24(3):383-408

Sims C, Finnoff D (2013) When is a "wait and see" approach to invasive species justified? Resour Energy Econ 35:235-255

Sims C, Finnoff D, Shogren JF (2016) Bioeconomics of invasive species: using real options theory to integrate ecology, economics, and risk management. Food Security 8:61-70

Springborn MR (2014) Risk aversion and adaptive management: insights from a multi-armed bandit model of invasive species risk. J Environ Econ Manag 68:226-242

Springborn M, Romagosa CM, Keller RP (2011) The value of nonindigenous species risk assessment in international trade. Ecol Econ 70:2145-2153

Springborn MR, Keller RP, Elwood S et al (2015) Integrating invasion and disease in the risk assessment of live bird trade. Divers Distrib 21:101-110

Springborn M, Lindsay AR, Epanchin-Niell RS (2016) Harnessing enforcement leverage at the border to minimize 
biological risk from international live species trade. J Econ Behav Org 132(B):98-112

Stohlgren TJ, Schnase JL (2006) Risk analysis for biological hazards: what we need to know about invasive species. Risk Anal 26(1):163-173

Surkov IV, Alfons GJM, Lansink O, Van der Werf W (2009) The optimal amount and allocation of sampling effort for plant health inspection. Eur Rev Agric Econ 36(3):295-320

Thomas MH, Randall A (2000) Intentional introductions of nonindigenous species: a principal-agent model and protocol for revocable decisions. Ecol Econ 34:333-345

Thompson CJ, Cannon RM, Burgman MA (2012) Surveillance for threatened and invasive species when uncertainty is severe. Divers Distrib 18(4):410-416

Tu AT, Beghin J, Gozlan E (2008) Tariff escalation and invasive species damages. Ecol Econ 67(4):619-629

Warziniack TW, Finnoff D, Shogren JF (2013) Public economics of hitchhiking species and tourism-based risk to ecosystem services. Resour Energy Econ 35(3):277-294
Wilen J (2007) Economics of spatial-dynamic processes. Am J Agric Econ 89:1134-1144

Wilson RS, Hardisty DJ, Epanchin-Niell RS, Runge MC, Cottingham KL, Urban DL, Maguire LA, Hasting AM, Mumby PJ, Peters DPC (2016) A typology of time-scale mismatches and behavioral interventions to diagnose and solve conservation problems. Conserv Biol 30(1):42-49

Wu J (2000) Optimal weed control under static and dynamic decision rules. Agric Econ 25(1):119-130

Yamamura K, Katsumata H, Yoshioka J, Yuda T, Kasugai K (2016) Sampling inspection to prevent the invasion of alien pests: statistical theory of import plant quarantine systems in Japan. Popul Ecol 58:63-80

Yemshanov D, Haight RG, Koch FH, Lu B, Venette R, Lyons DB, Scarr T, Ryall K, Leung B (2015) Optimal allocation of invasive species surveillance with the maximum expected coverage concept. Divers Distrib 21(11):1349-1359

Zavaleta E (2000) The economic value of controlling an invasive shrub. Ambio 29:462-467 